\title{
Hubungan Persepsi Terhadap Tuberkulosis Dengan Sikap Petugas Puskesmas Dalam Pencegahan Dan Pengendalian Infeksi Tuberkulosis Di Surakarta
}

\author{
Dinar Fatihah Fauzi ${ }^{1}$, Eti Poncorini Pamungkasari ${ }^{1}$, Balgis ${ }^{1}$ \\ 1. Fakultas Kedokteran Universitas Sebelas Maret
}

Korespondensi : dinar_fth@student.uns.ac.id

\begin{abstract}
ABSTRAK
Pendahuluan: Tuberkulosis merupakan salah satu dari 10 penyakit penyebab kematian tertinggi di dunia dan beban ekonomi tinggi yang dipikul akibat TB menyebabkan perlunya fasilitas pelayanan kesehatan yang terjangkau bagi pasien untuk mengurangi biaya transportasi. Oleh karena itu, perlu kesiapan petugas puskesmas dalam menangani pasien TB terutama dalam Pencegahan dan Pengendalian Infeksi Tuberkulosis (PPI TB). Penelitian ini bertujuan untuk mengetahui hubungan persepsi terhadap tuberkulosis dengan sikap petugas puskesmas dalam PPI TB.

Metode: Jenis penelitian ini adalah observasional analitik dengan pendekatan cross-sectional. Penelitian dilaksanakan di Surakarta pada November 2019. Teknik sampling yaitu total sampling pada seluruh petugas puskesmas di Surakarta yang berkaitan dengan pelayanan pasien tuberkulosis. Pengambilan data menggunakan kuesioner dan diperoleh sampel sejumlah 201 responden. Variabel bebas adalah persepsi petugas puskesmas terhadap tuberkulosis, sedangkan variabel terikat berupa sikap petugas puskesmas dalam PPI TB. Teknik analisis data menggunakan uji beda Mann-Whitney dan uji korelasi Spearmann.

Hasil dan pembahasan: Hubungan antara persepsi terhadap tuberkulosis dengan sikap petugas puskesmas dalam PPI TB tidak signifikan $(p=0,308)$. Diperoleh hubungan yang signifikan antara persepsi kerentanan $(p=0,015)$, persepsi ancaman $(p<0,001)$, persepsi manfaat $(p=0,005)$, dan stimulus tindakan $(\mathrm{p}=0,017)$ dengan sikap dalam PPI TB. Sedangkan persepsi keparahan $(\mathrm{p}=0,405)$ dan persepsi hambatan $(\mathrm{p}=0,362)$ berhubungan tidak signifikan secara statistik dengan sikap dalam PPI TB.

Kesimpulan: Tidak terdapat hubungan antara persepsi terhadap tuberkulosis dengan sikap petugas puskesmas dalam PPI TB di Surakarta. Persepsi kerentanan, persepsi ancaman, persepsi manfaat, dan stimulus tindakan memiliki hubungan yang signifikan dengan sikap dalam PPI TB.
\end{abstract}

Kata Kunci: persepsi; sikap; petugas puskesmas; tuberkulosis

\section{ABSTRACT}

Introduction: Tuberculosis is one of the 10 highest causes of death in the world and the economic burden borne by TB causes the need for affordable health care facilities for patients to reduce transportation costs. Therefore, it is necessary to prepare healthcare workers in handling TB patients, especially in Tuberculosis Infection Prevention and Control (IPC). This study aims to determine the relationship of perception of tuberculosis with the attitude of healthcare workers in Tuberculosis IPC.

Methods: This study was an analytic observational study with cross-sectional approach. This was conducted in Surakarta in November 2019. Sampling technique was total sampling of all healthcare workers related to tuberculosis services in primary health care facilities Surakarta. Questionnaire used in data collection and obtained 201 respondents. Independent variable was perception towards

Correspondence: Dinar Fatihah Fauzi, Fakultas Kedokteran Universitas Sebelas Maret, 
tuberculosis, while the dependent variable was attitude of healthcare workers in Tuberculosis IPC. Data analysis used Mann-Whitney test and Spearmann test.

Results and discussions: Relationship between perception of tuberculosis and attitude of healthcare workers in Tuberculosis IPC in Surakarta is not significant $(p=0.308)$. Perceived susceptibility $(p=$ $0.015)$, perceived threat ( $p<0.001)$, perceived benefits $(p=0.005)$, and cues to action $(p=0.017)$ have significant relationship with attitude in Tuberculosis IPC. Perceived severity $(p=0.405)$ and perceived barriers $(p=0.362)$ were not statistically significant related to attitude in Tuberculosis IPC.

Conclusion: There is non-significant relationship between perception of tuberculosis and attitude of healthcare workers in Tuberculosis IPC in Surakarta. Perceived susceptibility, perceived threat, perceived benefits, and cues to action have significant relationship with attitude in Tuberculosis IPC

Keywords: Perception, Attitude, Healthcare workers, Tuberculosis

\section{PENDAHULUAN}

Tuberkulosis merupakan salah satu dari 10 penyakit penyebab kematian tertinggi di dunia $^{1}$. Di Surakarta, penemuan kasus tuberkulosis (TB) menempati urutan ke 5 tertinggi di Jawa Tengah ${ }^{2}$.

Beban ekonomi tinggi yang dipikul akibat TB menyebabkan perlunya fasilitas pelayanan kesehatan yang terjangkau, dalam hal ini puskesmas, bagi pasien untuk mengurangi biaya transportasi ${ }^{3,4}$. Namun, semua jenis TB merupakan ancaman utama bagi petugas kesehatan di seluruh dunia ${ }^{5}$. Hal ini menyebabkan TB sebagai masalah kesehatan akibat kerja bagi petugas puskesmas karena mereka berisiko terinfeksi $\mathrm{TB}^{6}$. Oleh karena itu, perlu kesiapan petugas puskesmas dalam menangani pasien TB terutama dalam Pencegahan dan Pengendalian Infeksi Tuberkulosis (PPI TB).

Teori yang digunakan pada penelitian ini adalah Health Belief Model (HBM). Health Belief Model adalah teori perubahan perilaku yang berpusat pada individu ${ }^{6}$. Teori ini digunakan karena terdapat hal-hal yang mempengaruhi keputusan seseorang untuk bertindak dalam pencegahan, deteksi, dan pengendalian suatu penyakit. Hal pokok tersebut antara lain: persepsi kerentanan, persepsi keparahan, persepsi ancaman, persepsi manfaat, persepsi hambatan, dan stimulus tindakan ${ }^{8,9}$.

Penelitian ini bertujuan untuk mengetahui hubungan persepsi petugas Puskesmas terhadap tuberkulosis dengan sikap petugas Puskesmas dalam pencegahan dan pengendalian infeksi tuberkulosis.

\section{METODE}

Jenis penelitian ini adalah observasional analitik dengan pendekatan cross-sectional. Penelitian dilaksanakan di Surakarta pada November 2019. Teknik sampling yaitu total sampling pada seluruh petugas puskesmas di Surakarta yang berkaitan dengan pelayanan pasien tuberkulosis. Pengambilan data menggunakan kuesioner dan diperoleh 201 responden. Variabel bebas adalah persepsi petugas puskesmas terhadap tuberkulosis, sedangkan variabel terikat berupa sikap petugas puskesmas dalam PPI TB. Teknik analisis data menggunakan uji beda Mann-Whitney dan uji korelasi Spearmann. 


\section{HASIL DAN PEMBAHASAN}

Responden yang memenuhi kriteria inklusi dan eksklusi sebanyak 273 responden. Dari jumlah tersebut, sebanyak 72 responden mengisi kuesioner tidak lengkap. Profesi dengan jumlah data tidak lengkap tertinggi yaitu petugas farmasi (20 orang), sedangkan petugas pendaftaran hanya 6 orang dengan data tidak lengkap. Data yang lengkap diambil sebagai sampel sebanyak 201 responden.

\section{Analisis Univariat}

Tabel 1 menunjukkan distribusi responden penelitian berdasarkan usia, jenis kelamin, dan profesi. Responden dalam penelitian ini didominasi oleh usia 20 - 29 tahun yaitu sejumlah 64 responden $(31,8 \%)$. Responden paling sedikit berusia $\geq 50$ tahun sejumlah $14,4 \%$. Didapatkan 177 responden berjenis kelamin perempuan (88\%) dan 24 responden laki-laki (12\%). Responden terbanyak berprofesi sebagai perawat sejumlah 70 responden $(34,8 \%)$. Dari jumlah tersebut, terdapat perawat yang juga berperan sebagai petugas poli tuberkulosis.

Tabel 1 Distribusi Responden Penelitian Berdasarkan Usia, Jenis Kelamin, dan Profesi (n=201)

\begin{tabular}{|c|c|c|}
\hline Karakteristik & Jumlah & Persentase $(\%)$ \\
\hline \multicolumn{3}{|l|}{ Usia } \\
\hline $20-29$ & 64 & 31,8 \\
\hline $30-39$ & 62 & 30,9 \\
\hline $40-49$ & 46 & 22,9 \\
\hline$\geq 50$ & 29 & 14,4 \\
\hline \multicolumn{3}{|l|}{ Jenis Kelamin } \\
\hline Perempuan & 177 & 88 \\
\hline Laki-Laki & 24 & 12 \\
\hline \multicolumn{3}{|l|}{ Profesi } \\
\hline Dokter & 25 & 12,4 \\
\hline Perawat & 70 & 34,8 \\
\hline Analis Laboratorium & 17 & 8,5 \\
\hline Promosi Kesehatan & 16 & 8 \\
\hline Kesehatan Lingkungan & 12 & 6 \\
\hline Pendaftaran & 27 & 13,4 \\
\hline Farmasi & 34 & 16,9 \\
\hline
\end{tabular}

Distribusi responden penelitian berdasarkan persepsi dan sikap dapat dilihat pada tabel 2 . Skor minimal variabel persepsi terhadap tuberkulosis yaitu 38, skor maksimal 135, dan ratarata skor 105,04. Standar deviasi menunjukkan bahwa skor masih dapat meningkat atau menurun sampai maksimal 11,123. Terdapat lebih banyak responden (50,2\%) memiliki persepsi terhadap tuberkulosis yang rendah atau di bawah rata-rata. 
Pada variabel sikap dalam PPI TB diperoleh skor minimal 16, skor maksimal 32, rata-rata skor 25,44 , dan standar deviasi 2,988 . Sejumlah $52,2 \%$ responden memiliki sikap yang kurang dalam PPI TB.

Tabel 2 Distribusi Responden Penelitian Berdasarkan Persepsi dan Sikap

\begin{tabular}{lcccc}
\hline Karakteristik & Frekuensi & Persentase (\%) & Min-Max & Mean \pm SD \\
\hline $\begin{array}{l}\text { Persepsi terhadap Tuberkulosis } \\
\text { Rendah (< rata-rata }\end{array}$ & 101 & 50,2 & $38-135$ & $105,04 \pm$ \\
skor) & 100 & 49,8 & & 11,123 \\
Tinggi ( $\geq$ rata-rata skor) & & & & \\
Sikap dalam PPI TB & 105 & 52,2 & $16-32$ & $25,44 \pm 2,988$ \\
Kurang (< rata-rata skor) & 96 & 47,8 & & \\
Baik ( $\geq$ rata-rata skor) & & & & \\
Total & 201 & 100 & & \\
\hline
\end{tabular}

\section{Analisis Bivariat}

Data persepsi terhadap tuberkulosis terdistribusi tidak normal karena nilai p 0,016. Pada variabel persepsi kerentanan, keparahan, ancaman, manfaat, hambatan, stimulus tindakan, dan sikap dalam PPI TB didapatkan nilai $\mathrm{p}<0,001$. Hasil uji normalitas terdapat pada tabel 3 . Selanjutnya, dilakukan uji beda Mann-Whitney dan uji korelasi Spearmann untuk mengetahui korelasi antar variabel.

Tabel 3 Hasil Uji Normalitas Kolmogorov-Smirnov

\begin{tabular}{lc}
\hline \multicolumn{1}{c}{ Variabel } & $\mathrm{p}$ \\
\hline Persepsi terhadap Tuberkulosis & 0,016 \\
Persepsi Kerentanan & $<0,001$ \\
Persepsi Keparahan & $<0,001$ \\
Persepsi Ancaman & $<0,001$ \\
Persepsi Manfaat & $<0,001$ \\
Persepsi Hambatan & $<0,001$ \\
Stimulus Tindakan & $<0,001$ \\
Sikap dalam PPI TB & $<0,001$ \\
\hline
\end{tabular}

Hasil uji beda mean terlihat pada tabel 4. Terdapat perbedaan mean antara laki-laki dan perempuan secara signifikan pada variabel persepsi terhadap tuberkulosis $(\mathrm{p}=0,036)$, persepsi kerentanan $(\mathrm{p}=0,037)$, dan stimulus tindakan $(\mathrm{p}=0,025)$ dengan nilai $\mathrm{p}<0,05$. Sedangkan, perbedaan mean pada variabel persepsi keparahan $(\mathrm{p}=0,251)$, persepsi ancaman $(\mathrm{p}=0,314)$, persepsi manfaat $(\mathrm{p}=0,340)$, persepsi hambatan $(\mathrm{p}=0,942)$, dan sikap dalam PPI TB $(\mathrm{p}=0,065)$ tidak signifikan antara laki-laki dan perempuan karena nilai $\mathrm{p}>0,05$.

Pada uji korelasi Spearmann diperoleh nilai p 0,308 untuk persepsi terhadap tuberkulosis dengan sikap dalam PPI TB, sehingga korelasi antara kedua variabel tidak signifikan. Persepsi kerentanan $(\mathrm{p}=0,015)$, persepsi ancaman $(\mathrm{p}<0,001)$, persepsi manfaat $(\mathrm{p}=0,005)$, dan stimulus 
tindakan $(\mathrm{p}=0,017)$ memiliki hubungan yang signifikan dengan sikap dalam PPI TB. Sedangkan persepsi keparahan $(\mathrm{p}=0,405)$ dan persepsi hambatan $(\mathrm{p}=0,362)$ berhubungan tidak signifikan secara statistik dengan sikap dalam PPI TB. Hasil uji korelasi Spearmann terdapat pada tabel 5.

Tabel 4 Hasil Uji Beda Mann-Whitney

\begin{tabular}{lccc}
\hline \multicolumn{1}{c}{ Variabel } & & Mean & $\mathrm{p}$ \\
& Laki-laki & Perempuan & \\
\hline $\begin{array}{l}\text { Persepsi terhadap } \\
\text { Tuberkulosis }\end{array}$ & 77,65 & 104,17 & 0,036 \\
Persepsi Kerentanan & 77,83 & 104,14 & 0,037 \\
Persepsi Keparahan & 88,35 & 102,71 & 0,251 \\
Persepsi Ancaman & 89,83 & 102,51 & 0,314 \\
Persepsi Manfaat & 90,96 & 102,36 & 0,340 \\
Persepsi Hambatan & 101,79 & 100,89 & 0,942 \\
Stimulus Tindakan & 76,60 & 104,31 & 0,025 \\
Sikap dalam PPI TB & 121,46 & 98,23 & 0,065 \\
\hline
\end{tabular}

Tabel 5 Hasil Uji Korelasi Spearmann Variabel Persepsi dengan Sikap dalam PPI TB

\begin{tabular}{lc}
\multicolumn{1}{c}{ Variabel Persepsi } & $\mathrm{p}$ \\
\hline Persepsi terhadap Tuberkulosis & 0,308 \\
Persepsi Kerentanan & 0,015 \\
Persepsi Keparahan & 0,405 \\
Persepsi Ancaman & $<0,001$ \\
Persepsi Manfaat & 0,005 \\
Persepsi Hambatan & 0,362 \\
Stimulus Tindakan & 0,017
\end{tabular}

Pengambilan data dilaksanakan di seluruh puskesmas di Surakarta. Surakarta dipilih karena penemuan kasus TB BTA positif menempati urutan kelima di Jawa tengah dengan jumlah penemuan kasus 134,7 per 100.000 penduduk $^{2}$.

Penelitian pada petugas puskesmas dilaksanakan karena pengobatan TB saat ini diarahkan ke puskesmas untuk mengurangi beban ekonomi. Beban ekonomi akibat TB yang tinggi menyebabkan pentingnya peran fasilitas pelayanan kesehatan terdekat, dalam hal ini puskesmas, untuk mengurangi biaya transportasi pasien $\mathrm{TB}^{3,4}$.

\section{Karakteristik Responden Penelitian}

Pada hasil analisis univariat, responden penelitian sejumlah 201 orang. Responden terbanyak berusia 20-29 tahun dengan jumlah 64 orang $(31,8 \%)$. Hal ini sesuai dengan penelitian Van Rie dkk. dengan mayoritas responden berusia 20-29 tahun sejumlah 37 orang 
(30,8\%). Mayoritas dari responden adalah perempuan dengan jumlah 177 responden (88\%). Van Rie dkk. juga menyebutkan bahwa $88,3 \%$ dari respondennya adalah perempuan ${ }^{10}$.

Profesi responden terbanyak pada penelitian ini adalah perawat sejumlah 69 orang $(34,3 \%)$ dan petugas farmasi 34 orang (16,9\%). Jumlah profesi perawat dalam responden penelitian Aluko dkk. juga merupakan mayoritas hingga 52,4\% ${ }^{11}$. Namun, pada penelitian tersebut hanya profesi dokter, perawat, dan asisten perawat yang diambil sebagai responden. Berbeda dengan penelitian ini yang mengambil responden pada seluruh profesi dengan kemungkinan kontak dengan pasien TB baik perawat yang sekaligus menjadi petugas poli tuberkulosis, dokter, bagian pendaftaran, farmasi, promosi kesehatan, kesehatan lingkungan, maupun analis laboratorium.

\section{Persepsi Petugas Puskesmas terhadap Tuberkulosis}

Persepsi diartikan sebagai sesuatu yang dialami manusia, timbul karena input pengindraan dan bagaimana manusia memproses informasi melalui input tersebut ${ }^{12}$. Variabel persepsi memiliki rata-rata skor 105,04 . Sejumlah 100 responden $(49,8 \%)$ memiliki persepsi tinggi dengan skor di atas rata-rata dan 101 responden (50,2\%) memiliki persepsi rendah dengan skor di bawah rata-rata.. Hal ini menunjukkan bahwa lebih banyak petugas puskemas memiliki persepsi yang rendah terhadap tuberkulosis.

Persepsi dengan skor di bawah rata-rata terdapat pada 46,3\% responden perempuan dan $79,2 \%$ responden laki-laki. Persepsi yang rendah dapat disebabkan oleh beberapa faktor. Faktorfaktor yang mempengaruhi persepsi seseorang antara lain kondisi fisik, sosial-psikologis, tingkat pendidikan, jenis profesi, dan pengetahuan ${ }^{13,14,15}$. Aluko dkk. juga menyebutkan adanya hubungan antara status perkawinan, agama, dengan persepsi petugas puskesmas terhadap risiko terkena penyakit saat bekerja ${ }^{11}$.

\section{Sikap Petugas Puskesmas dalam PPI TB}

Sikap merupakan evaluasi positif-negatif, baik-buruk, menyenangkan-tidak menyenangkan terhadap suatu objek atau keadaan. Sikap ini selanjutnya akan menjadi suatu potensi reaksi terhadap objek sikap $(16,17)$. Dari hasil analisis, untuk variabel sikap diperoleh rata-rata skor 25,44. Sebanyak 96 responden (47,8\%) memperoleh skor di atas rata-rata dan 105 responden $(52,2 \%)$ di bawah rata-rata. Berdasarkan data tersebut, lebih banyak responden dengan sikap kurang.

Sebanyak 54,2\% responden perempuan dan 37,5\% responden laki-laki memiliki sikap yang kurang dalam PPI TB. Sikap yang kurang dapat dipengaruhi oleh beberapa faktor. Berdasarkan penelitian Alotaibi dkk. usia dan profesi berhubungan dengan sikap petugas dalam pengendalian tuberculosis ${ }^{18}$. Adanya hubungan antara etnis, agama, dan jenis kelamin dengan sikap petugas puskesmas disebutkan dalam penelitian Aluko dkk ${ }^{11}$. Selain itu, faktor-faktor yang mempengaruhi sikap seseorang antara lain kebudayaan, emosi, pengetahuan, dan pendidikan kesehatan ${ }^{16,17,19,20,21}$. Mustariningrum dkk. dalam penelitiannya menyebutkan bahwa program pelatihan PPI dasar dapat meningkatkan sikap perawat dalam pengendalian infeksi ${ }^{22}$. Sedangkan, pada penelitian ini tidak mencakup semua faktor-faktor yang mempengaruhi sikap seseorang.

\section{Perbedaan Mean Berdasarkan Jenis Kelamin}

Berdasarkan hasil uji beda Mann-Whitney, terdapat perbedaan mean antara laki-laki dan perempuan secara signifikan pada variabel persepsi terhadap tuberkulosis $(\mathrm{p}=0,036)$. Diperoleh rata-rata skor responden laki-laki lebih rendah daripada perempuan, dengan skor 77,65 dan 
104,17. Hal ini didukung oleh penelitian Soo-Jung dan Jiyeon, terdapat perbedaan nilai rata-rata persepsi terhadap tuberkulosis antara perawat laki-laki dan perempuan $(\mathrm{p}=0,003)^{23}$. Pada penelitian tersebut, rata-rata skor laki-laki lebih rendah daripada perempuan. Hal ini disebabkan karena perempuan cenderung mengalami kecemasan yang lebih tinggi daripada laki-laki ${ }^{24}$. Kecemasan tersebut menimbulkan persepsi kerentanan akan terkena penyakit, keparahan penyakit, dan ancaman yang dirasakan terhadap suatu penyakit sehingga rata-rata skor persepsi terhadap tuberkulosis pada perempuan lebih tinggi.

Persepsi kerentanan $(\mathrm{p}=0,037)$ dan stimulus tindakan $(\mathrm{p}=0,025)$ memiliki rata-rata skor yang berbeda secara signifikan antara laki-laki dan perempuan. Sedangkan, perbedaan mean pada variabel persepsi keparahan $(\mathrm{p}=0,251)$, persepsi ancaman $(\mathrm{p}=0,314)$, persepsi manfaat $(\mathrm{p}=0,340)$, persepsi hambatan $(\mathrm{p}=0,942)$ tidak signifikan antara laki-laki dan perempuan karena nilai $\mathrm{p}>0,05$.

Skor pada variabel sikap dalam PPI TB $(\mathrm{p}=0,065)$ memiliki perbedaan raa-rata yang signifikan antara perempuan dan laki-laki. Hal ini didukung oleh penelitian Aluko dkk. yang menyebutkan adanya hubungan yang signifikan antara jenis kelamin dan sikap dalam keselamatan kerja ${ }^{11}$.

\section{Hubungan Persepsi terhadap Tuberkulosis dengan Sikap dalam PPI TB}

Untuk mengetahui hubungan antara dua variabel, dilakukan uji korelasi Spearmann pada variabel persepsi terhadap tuberkulosis dan sikap petugas puskesmas dalam PPI TB. Diperoleh nilai $p$ 0,308 sehingga hubungan tidak signifikan karena $p>0,05$. Artinya, hubungan antara persepsi terhadap tuberkulosis dengan sikap dalam PPI TB tidak bermakna secara statistik.

Persepsi terhadap tuberkulosis kemudian dianalisis per domain untuk mengetahui hubungannya dengan sikap dalam PPI TB. Diperoleh hubungan yang signifikan antara persepsi kerentanan $(\mathrm{p}=0,015)$, persepsi ancaman $(\mathrm{p}<0,001)$, persepsi manfaat $(\mathrm{p}=0,005)$, dan stimulus tindakan $(\mathrm{p}=0,017)$ dengan sikap dalam PPI TB. Sedangkan persepsi keparahan $(\mathrm{p}=0,405)$ dan persepsi hambatan $(\mathrm{p}=0,362)$ berhubungan tidak signifikan secara statistik dengan sikap dalam PPI TB.

Hasil pada penelitian ini didukung oleh penelitian Ningrum yang menyebutkan bahwa persepsi manfaat dan stimulus tindakan memiliki hubungan positif yang bermakna dengan kinerja kader dalam PPI $\mathrm{TB}^{25}$. Lestari dkk. juga menyatakan adanya hubungan signifikan antara persepsi berisiko atau kerentanan dengan perilaku pencegahan penularan penyakit pada petugas puskesmas dengan nilai $\mathrm{p} 0,001^{26}$.

Pada penelitian Agung dkk perilaku deteksi dini tuberkulosis dipengaruhi oleh persepsi kerentanan dan ancaman, namun tidak dipengaruhi secara bermakna oleh persepsi keparahan dan hambatan ${ }^{27}$. Hal ini mendukung hasil penelitian bahwa persepsi kerentanan dan ancaman berpengaruh signifikan terhadap sikap. Selain itu diperoleh hubungan tidak signifikan antara persepsi keparahan dan persepsi hambatan dengan sikap dalam PPI TB, salah satunya deteksi dini tuberkulosis. Hasil penelitian juga sejalan dengan penelitian Dewi, dimana persepsi kerentanan $(\mathrm{p}=0,034)$ dan persepsi ancaman $(\mathrm{p}=0,035)$ berhubungan signifikan dengan peran Pengawas Minum Obat (PMO) dalam pemberian obat $\mathrm{TB}^{28}$.

Hasil pada penelitian ini tidak sesuai dengan penelitian Agiviana dimana ada hubungan signifikan antara persepsi dengan perilaku keselamatan karyawan ${ }^{29}$. Ningrum (2016) juga menyebutkan terdapat hubungan signifikan antara persepsi keparahan dan persepsi hambatan dengan kinerja kader dalam PPI TB ${ }^{25}$. 
Runtu dkk. dalam penelitiannya menyatakan bahwa persepsi risiko infeksi atau kerentanan tidak berpengaruh signifikan terhadap perilaku perawat dalam pencegahan infeksi ${ }^{21}$. Selain itu, persepsi manfaat tidak berpengaruh secara bermakna terhadap perilaku deteksi dini tuberkulosis ${ }^{27}$.

Kelemahan dalam penelitian ini yaitu kurangnya pendampingan responden oleh peneliti saat pengisian kuesioner. Hal ini karena kuesioner diberikan dan diambil pada hari yang berbeda. Hambatan yang terjadi yaitu petugas kesehatan di saat jam kerja melakukan tugas pelayanan, sedangkan di luar jam kerja memiliki kesibukan lain, sehingga mempersulit pengumpulan kuesioner di hari yang sama saat dibagikan.

Selain itu, terdapat 72 dari 273 responden yang tidak lengkap dalam pengisian kuesioner. Sehingga kemungkinan didapatkan bias sampling dimana missing data sejumlah $26 \%$.

Petugas farmasi memiliki persentase missing data tertinggi yaitu 37\%, sehingga hasil pada penelitian ini kurang representatif untuk profesi petugas farmasi. Untuk petugas pendaftaran hanya $18,2 \%$ data yang tidak lengkap, sehingga hasil penelitian cukup representatif untuk petugas pendaftaran.

Dalam penelitian ini hanya dilakukan analisis hubungan antara persepsi dengan sikap. Faktor-faktor lain yang mempengaruhi sikap seperti usia, profesi, etnis, agama, jenis kelamin, kebudayaan, emosi, pengetahuan, pendidikan kesehatan, dan program pelatihan PPI dasar tidak dianalisis dalam penelitian ini. Hal ini dapat mempengaruhi hasil penelitian.

\section{KESIMPULAN}

Tidak terdapat hubungan antara persepsi terhadap tuberkulosis dengan sikap petugas puskesmas dalam pelaksanaan PPI TB. Persepsi kerentanan, persepsi ancaman, persepsi manfaat, dan stimulus tindakan memiliki hubungan yang signifikan dengan sikap dalam PPI TB.

\section{UCAPAN TERIMA KASIH}

Penulis mengucapkan terima kasih kepada Ari Natalia Probandari, dr, MPH, Ph.D yang telah memberikan bimbingan, saran, dan kritik yang membangun selama penelitian hingga penulisan naskah publikasi ini.

\section{DAFTAR PUSTAKA}

1. WHO. Global Tuberculosis Report 2018. Geneva; 2018.

2. Dinas Kesehatan Provinsi Jawa Tengah. Profil Kesehatan Provinsi Jawa Tengah 2017 [DINKES]. 2017.

3. Tanimura T, Jaramillo E, Weil D, Raviglione M. Financial burden for tuberculosis patients in low- and middle-income countries: a systematic review. Eur Respir J. 2014;43:1763-75.

4. Collins D, Hafidz F, Mustikawati D. The economic burden of tuberculosis in Indonesia. Int J Tuberc Lung Dis. 2017;21(9):1041-8.

5. Von Delft A, Dramowski A, Khosa C, Kotze K, Lederer P, Mosidi T, et al. Why Healthcare Workers are Sick of TB. Int J Infect Dis. 2015;32:147-51.

6. Anggraini RD, Rahayu EP, Aminuzzab A. Policy Brief: Penelusuran Ancaman Kasus TB pada Petugas Kesehatan di Indonesia. Yogyakarta; 2018.

7. Green EC, Murphy E. Health Belief Model. In: The Wiley Blackwell Encyclopedia of Health, Illness, Behavior, and Society. First Edit. John Wiley \& Sons, Ltd; 2014. p. 1-4. 
8. Butts JB, Rich KL. Philosophies and Theories for Advanced Nursing Practice (3rd ed.). Burlington MA: Jones \& Bartlett Learning; 2017.

9. Glanz K, Rimer KB, Viswanath K. Health Behavior: Theory, Research, and Practice (5th Edition). San Francisco, CA: Jossey-Bass; 2015.

10. Van Rie A, Mccarthy K, Scott L, Dow A, Venter WDF, Stevens WS. Prevalence, risk factors and risk perception of tuberculosis infection among medical students and healthcare workers in Johannesburg, South Africa. South African Med J. 2013;103(11):853-7.

11. Aluko OO, Adebayo AE, Adebisi TF, Ewegbemi MK. Knowledge, attitudes, and perceptions of occupational hazards and safety practices in Nigerian healthcare workers. BMC Res Notes. 2016;9(71):1-14.

12. Riyanti BPD, Prabowo H, Puspitawati I. Psikologi Umum 1 [Internet]. 2011. Available from: http://elearning.gunadarma.ac.id/docmodul/psikologi_umum_1/Bab_3.pdf

13. Thalib SB. Psikologi Pendidikan Berbasis Analisis Empiris Aplikatif. 1st ed. Jakarta: Kencana; 2010.

14. Tziaferi SG, Sourtzi P, Kalokairinou A, Sgourou E, Koumoulas E, Velonakis E. Risk Assessment of Physical Hazards in Greek Hospitals Combining Staff' s Perception, Experts' Evaluation and Objective Measurements. Saf Health Work [Internet]. 2011;2(3):260-72. Available from: http://dx.doi.org/10.5491/SHAW.2011.2.3.260

15. Sima BT, Belachew T, Abebe F. Health care providers 'knowledge, attitude and perceived stigma regarding tuberculosis in a pastoralist community in Ethiopia : a cross-sectional study. BMC Health Serv Res. 2019;19(19):1-11.

16. Azwar S. Sikap Manusia Teori dan Pengukurannya Edisi ke 2. Yogyakarta: Pustaka Pelajar; 2016.

17. Riyanti BPD, Prabowo H. Psikologi Umum 2 [Internet]. 2011. Available from: http://elearning.gunadarma.ac.id/docmodul/psikologi_umum2/bab4_sikap_manusia.pdf

18. Alotaibi B, Yassin Y, Mushi A, Maashi F, Thomas A, Mohamed G, et al. Tuberculosis Knowledge, Attitude and Practice Among Healthcare Workers during the 2016 Hajj. PLoS One. 2019;14(1):1-15.

19. Hepriyansori, Tamimi I. Hubungan Pengetahuan Dan Sikap Petugas Laboratorium Kesehatan Terhadap Penggunaan Alat Pelindung Diri. J Ilm Pharm. 2019;6(1):86-93.

20. Sakti YBH, Ratnasari D. Hubungan Pendidikan Kesehatan dengan Perubahan Sikap Penderita Tuberkulosis yang Berobat di Puskesmas Karanganyar, Kebumen. Herb-Medicine J. 2019;2(1):22-7.

21. Runtu LG, Haryanti F, Rahayujati TB. Faktor-Faktor yang Berhubungan dengan Perilaku Perawat Dalam Penerapan Universal Precautions di RSUP Prof. Dr. R. D. Kandou Manado. Juiperdo. 2013;2(1).

22. Mustariningrum DLT, Koeswo M, Ahsan. Kinerja IPCLN dalam Pencegahan dan Pengendalian Infeksi di Rumah Sakit: Peran Pelatihan, Motivasi Kerja dan Supervisi. J Apl Manaj. 2015;13(4):643-52.

23. Soo-Jung K, Jiyeon K. Emergency Nurses' Perception and Performance of Tuberculosis Infection Control Measures. J Korean Acad Fundam Nurs. 2010;17(3):351-61.

24. Havivah. Gambaran Tingkat Kecemasan Pasien pre Operasi Katarak di Kabupaten Jember [Internet]. Universitas Jember; 2019. Available from: https://repository.unej.ac.id/bitstream/handle/123456789/91071/Havivah-

152310101173.pdf? sequence $=1 \&$ isAllowed $=y$

25. Ningrum D. Path Analysis Hubungan Pendidikan dan Konstruk Health Belief Model dengan Kinerja Kader pada Pengendalian Kasus Tuberkulosis di Puskesmas Baki Kabupaten Sukoharjo [Internet]. Universitas Sebelas Maret; 2016. Available from: https://abstrak.uns.ac.id/wisuda/upload/s021408013_pendahuluan.pdf

26. Lestari FA, Suarnianti, Hasifah. Hubungan Faktor Individu dengan Perilaku Pengurangan Risiko Penularan Penyakit pada Petugas Kesehatan di Puskesmas Tamalanrea Kota Makassar. J Ilm Kesehat Diagnosis. 2019;13(6):710-5. 
27. Agung AAG, Sawitri AAS, Wirawan DN. Laporan hasil penelitian Rendahnya proporsi kontak yang melakukan deteksi dini tuberkulosis paru di Puskesmas I Denpasar Selatan tahun 2012 Low proportion of contact among people attending early detection for pulmonary tuberculosis in Denpasar Selatan I c. Public Heal Prev Med Arch. 2013;1(1):55-62.

28. Dewi II. Analisis Faktor yang Berhubungan dengan Peran PMO dalam Pemberian Obat TB terhadap Pencegahan Kejadian Drop Out (Studi pada PMO TB Anak) [Internet]. Universitas Diponegoro; 2019. Available from: http://eprints.undip.ac.id/77529/1/6889.pdf

29. Agiviana AP, Djastuti I. Analisis Pengaruh Persepsi, Sikap, Pengetahuan dan Tempat Kerja terhadap Perilaku Keselamatan Karyawan. Diponegoro J Manag [Internet]. 2015;4(3):1-9. Available from: http://ejournal-s1.undip.ac.id/index.php/dbr 